\title{
Síndrome dos ovários policísticos o visível e o invisível inerentes ao risco cardiovascular
}

\author{
Polycystic ovary syndrome: the visible and invisible associate with \\ cardiovascular risk
}

tCBC RJ Márcio Augusto Pinto de Ávila

Faculdade de Medicina da Universidade Federal do Rio de Janeiro (UFRJ).

$T^{\text {ne }}$ homas Mann em "A Montanha Mágica" (1924) escreve a respeito do enquadramento físico frente à doença: "Pois a doença faz o homem mais corporal, torna-o corpo e nada mais...". Assim se expressam os dissabores que ferem a auto-estima e imprimem à natureza humana a preocupação restrita à corporalidade, sobretudo em face de certo elenco sintomático.

Considerada a endocrinopatia feminina mais incidente, cerca de $5-10 \%$ da população, a síndrome dos ovários policísticos (SOP) detém o lastro histórico e enigmático no que concerne a heterogeneidade fenotípica, consubstanciada pelos enlaces endócrinos e metabólicos como pano de fundo de associações mórbidas, diversificadas quanto à gravidade clínica. Por outro lado, em razão de evidências corpóreas depreciativas, especialmente o hirsutismo, a acne vulgar e a alopecia andrógena, a SOP faz jus ao emblemático veredicto - "the thief of womanhood" ("o ladrão da identidade feminina")1. Além disso, a intervenção da obesidade, componente incluído no relato primeiro de Irving Stein e Michael Leventhal ${ }^{2}$, em 1935, contribui (entre outros males) para diminuir o ânimo e debilitar a qualidade de vida. As implicações se estendem à síndrome depressiva, afora as referências clássicas, regidas pelo hiperandrogenismo, ou seja, as irregularidades do ciclo menstrual, as demais alterações cutâneas, a infertilidade e a possibilidade quanto ao surgimento de neoplasia do endométrio. Importa, ainda, distinguir a circunstância infensa em relação à condição materno-fetal, desde os primórdios do período gravídico, a propósito de ingerir-se sobre a placentação, o desenvolvimento do concepto e a glicemia materna. Todavia, há que referir a ocorrência de manifestação atenuada da SOP (comprovada a ovulação) ou praticamente indistinguível dos padrões normais (em ausência de hiperandrogenismo).

Em contraposição aos estigmas explícitos, afloram num campo "dissimulável" as perturbações metabólicas, suscetíveis de evolução "silenciosa" e comprometimentos graves no longo termo. Nesse sentido, dentre as perspectivas que compõem o quadro fenotípico no decurso da SOP, ganha importância à resistência à insulina (RI) acompanhada pela hiperinsulinemia de par com anormalidades várias, vez por outra ainda incipientes, a partir de uma "Causa" que se remete a "cumplicidade" entre genes e estilo de vida. Desde o século passado, a correspondên- cia entre as desordens do metabolismo dos carboidratos e o hiperandrogenismo, divulgada primeiramente por Achard e Thiers", em 1921 - "diabète des femmes à barbe" ("diabete de mulheres com barba") -, enseja os postulados referentes aos interesses tecidos à SOP investida da composição tácita, isto é, a disfunção metabólica. As pesquisas apontam a crescente ameaça vis-à-vis ao desenvolvimento da hiperglicemia independentemente da idade ou peso. Entretanto, a RI (isoladamente) e o ganho ponderal ostensivo completam-se de modo adverso. A confluência expõe o fato de, em grande parte, a obesidade incluir-se no quadro da SOP e precipitar o aparecimento de intolerância à glicose para a terceira e quarta décadas ou, de vez, a irrupção da diabete tipo 2 ao término da adolescência.

A constituição do distúrbio metabólico denominado 'Síndrome $X$ ', conforme estipulado por Gerald Reaven ${ }^{4}$, em 1988, confere oportunidade a formulações similares quando um novo componente em seguida se sobressai, o aumento da adiposidade na região abdominal, conjuminado aos distúrbios da intolerância à glicose, a hipertrigliceridemia e a hipertensão. Nos anos que seguem, pesquisadores empregam o termo "síndrome da resistência à insulina", à medida que creditam à sensibilidade insulínica inadequada a circunstância subjacente e antecessora ao agravamento da constelação de fatores de risco. Compõe-se, desse modo, a relevância em caracterizar de imediato ou pressagiar no longo termo a condição vulnerável, em especial mediante o epíteto significativo de síndrome metabólica (SM), enunciada como o agrupamento de múltiplos fatores de risco cardiovascular que se interrelacionam. Trata-se, portanto, de constructo mesclado aos estigmas clássicos da SOP - anovulação e hiperandrogenismo. Nesse prosseguimento, ressalte-se, entre outros, a gravidade maior de sobrevir o estado diabético.

Não obstante a SOP detenha os atributos contundentes, desde a adolescência e acentuados no período de vida reprodutivo, após o desfecho da fertilidade e intensificação da senescência dos eixos hormonais, os efeitos lesivos, até então se acaso imperceptíveis senão negligenciados, tendem a morbidez mais pronunciada. A esse respeito, os danos em virtude da Rl já se generalizaram (tecido adiposo, fígado, músculo, etc.) e repercutem, 
notadamente, na intimidade do sítio vascular. Admite-se, consoante as desordens cumulativas do metabolismo, a sucessão de eventos que na fase inicial se coadunam pela disfunção endotelial restrita e, mais adiante, culminam no processo aterosclerótico.

Quanto aos ovários, especula-se à conta de mais verossímil expressarem maior sensibilidade à insulina, cuja atuação, direta ou indireta (hipófise) por intermédio do aumento da exposição ovariana ao hormônio luteinizante $(L H)$, em grau a princípio moderado, tende, contudo, à intensificação. Considera-se, assim, o efeito paradoxal (posto que sensíveis os ovários a insulina, ao contrário dos demais órgãos e sistemas) sobre grupos enzimáticos integrados no âmbito da esteroidogênese ovariana, quando o desenlace hormonal condiz com a síntese aumentada dos androgênios. Efetivamente, as "relações perigosas" hiperinsulinemia e hiperandrogenemia - num ritmo escalonado, em paralelo à falência de modo pausado das células beta do pâncreas, fazem ver os efeitos deletérios do excesso. Num ângulo tangente, cumpre salientar a presença de disfunção metabólica com base em distintos marcadores de risco vascular, conquanto não incluídos nas classificações em voga referentes à SM.

Não menos essencial, a despeito de evidências corporais depreciativas, especialmente o hirsutismo e a acne, que se proceda à verificação rotineira da coexistência de um indicador visível, embora, por vezes, menos aparente, ou seja, a acantose nigricante, particularmente relacionada a RI, a obesidade, a diabete e a SOP. Com efeito, a representação que se imprime ao correlacionar tal dermatose com o elenco metabólico atípico, ratifica as pressuposições inerentes aos caracteres da SOP prevalecida de maior risco cardiovascular. Nessa acepção, aglutinam-se os marcadores da homeostase imperfeita, enquanto, no rol das estatísticas, dissociável o fator etário (durante o tempo reprodutivo, em tese) na gênese de injunções epidêmicas, diga-se, a obesidade, a síndrome depressiva, a doença vascular (extensível à diabete tipo 2); enleio propenso a acrescer o impacto atribuído à SOP constituída com a nocividade que se amplia. Cuida-se, assim, em detectar o agravo preexistente ou mesmo impedir oportunamente o seu desenvolvimento, tão logo se confirme o diagnóstico da SOP infligida pela coexistência de fatores de risco para a diabete tipo 2 e a doença cardiovascular, em prol do incontestável benefício que se exerce na esfera da saúde pública. Nesse feitio, como em tantos outros, não se igno- ra a incompletude de estudos que se prevejam capazes de contemplar a interseção de desígnios genéticos e a constelação de motivos à sombra de diversas predisposições orgânicas. As conferências, nesse quesito, ainda pendem sobre o embate entre o suposto e o improvável.

Convém, portanto, agenciar o tirocínio clínico para as dimensões do padrão cultural contemporâneo, pleno de urgências. Indeclinável o conjunto de incidentes que ferem a qualidade de vida, de sorte que se conclui decisiva a inclusão oportuna das artes preventivas a fim de restaurar os danos iniciais - o visível e o invisível - como que imperceptíveis. O remedeio corpóreo, de acordo

com a perspectiva de uma reformulação íntima, impõe atitudes que desafiem os hábitos cotidianos, sedentários no plano físico e psíquico, impulsivos ao relegar a ancestralidade do pensamento. Tal o conhecimento em curso, imprevisto antes, pois imprescindível agora, visto que, a espaços, no recinto orgânico, prospera a degeneração disseminada que intensifica e conduz, entre outros males, à senectude intelectiva precoce. Não sem razão que semelhantes aspectos mereceram o título - "diseases of Western civilization" (doenças da civilização ocidental) (Nesse \& Williams, 1994)6.

O risco cardiovascular é o signo de tal contingência evolutiva: permeia o conflito insondável de sensações, céleres e de encontro aos anseios de uma estética ávida de se recompor pela "alquimia" da imagem e do espírito.

\section{REFERÊNCIAS}

1. Kitzinger C, Willmott J. 'The thief of womanhood': women's experience of polycycstic ovarian syndrome. Soc Sci Msd. 2002; 54: 349-361.

2. Stein IF and Leventhal ML. Amenorrhea associated with bilateral polycystic ovaries. Am J Obstet Gynecol. 1935; 29: 181-191.

3. Achard $M C$ et Thiers MJ. Le virilism pilaire et son association à I'insuffisance glycolytique ("diabète des femmes à barbe"). Bulletin Academic National Medicine (Paris). 1921; 86: 51-64.

4. Reaven GM. Role of insulin resistance in human disease. Diabetes. 1988; 37: 1595-1607.

5. Nesse RM and Williams GC. 1994. Why we get sick. NewYork: Random House. In: Eisenmann JC. Secular Trends in Variables Associated With the Metabolic Syndrome of North American Children and Adolescents: A Review and Synthesis. Am J Hum Biol 2003; 15: 786-794 